Discussion Paper No. 705

INFORMATION AND DISCLOSURE IN STRATEGIC TRADE POLICY

\author{
Anthony Creane \\ and \\ Kaz Miyagiwa
}

December 2007

The Institute of Social and Economic Research Osaka University

6-1 Mihogaoka, Ibaraki, Osaka 567-0047, Japan 


\title{
Information and disclosure in strategic trade policy*
}

\author{
Anthony Creane $e^{\dagger}$ and Kaz Miyagiwa ${ }^{\ddagger}$
}

Abstract: We relax the standard assumption in the strategic trade policy literature that governments possess complete information about the economy. Assuming instead that governments must obtain information from firms, we examine firms' incentive to disclose information to the governments in the Brander-Spencer setting. With quantity competition, we find firms disclosing both demand and cost information, thereby justifying the literature's omniscient-government assumption. With price competition, however, firms have no incentives to disclose demand or cost information, so governments remain uninformed. Further, with quantity competition and unknown demand, governments are caught in an informational prisoner's dilemma.

Keywords: information, uncertainty, learning, prisoner's dilemma, strategic trade

JOE Classification code: F12, F13

${ }^{\dagger}$ Department of Economics, Michigan State University

*Department of Economics, Emory University, and ISER, Osaka University

Corresponding Author: Kaz Miyagiwa, The Institute of Social and Economic Research, Osaka University, 6-1 Mihogaoka, Ibaraki, Osaka 567-0047, Japan. Telephone: 81-6-6879-8556. FAX: 81-66878-2766. E-mail: kmiyagi@emory.com

\footnotetext{
* We would like to thank two anonymous referees, participants at the Midwest International Trade (2005) and the Asia-Pacific Trade Seminars (2005) meetings as well as seminar participants at Hitotsubashi University, Aoyama Gakuin University and Boston College for their helpful comments. Creane wishes to thank the Department of Economics at Boston College for their hospitality while completing this paper.
} 


\section{Introduction}

In their seminal publication Brander and Spencer (1985) demonstrated that, in the presence of international oligopolies, strategic use of export subsidies can improve a country's welfare at the expense of other countries. While their work has stimulated innumerable extensions and applications, subsequent writers have discovered that their main result is sensitive to the model's key assumptions. For example, when price competition is substituted for quantity competition in the Brander-Spencer model, the optimal policy switches from export subsidies to export taxes (Eaton and Grossman, 1986).

Subtler but equally controversial in the Brander-Spencer model is the assumption that governments have complete information about the economy. Even if governments actually possess such information, it still begs the question of how or from where they obtain such information. A natural candidate for the source of this information must be firms, but one may wonder if firms could ever have an incentive to share their information with the governments. Our primary objective is to examine under what conditions firms choose to disclose information to the governments

To explore this issue we start with our basic understanding that government policies are rarely a one-time event, but rather there is a long-term relationship between the government and the firm. The firm possessing private information understands that over time market conditions vary in unpredictable ways. As a result, although at a given point in time it may not want to disclose information because of its adverse effect on the government's policy, the firm may still benefit from entering into a long-term agreement to disclose future information to the government.

If the firm and the government have entered into such an agreement, the government will be constantly updated with information and be able to adjust its trade policy accordingly. However, such discretion in trade policy can, in the presence of international rivalry, put the government at a strategic disadvantage against an uninformed foreign government which cannot adjust its policy to new 
information. Thus, in answering our first question, a surprising second question arises: would governments want information from firms?

To examine these questions, we adopt the Brander-Spencer setting, in which two firms from two separate countries compete in a third-country market. Firms and governments operate in the environment in which demand and costs fluctuate, and new parameter values are revealed to firms but not to governments. Our model proceeds in four stages. In the first stage, the firm and the government in each country simultaneously decide whether to disclose and to receive future information, respectively. If both agree, then they create an institutional structure to have verifiable information disclosure, both incurring setup costs, which are assumed arbitrarily small. ${ }^{1}$ In stage two, nature selects new values for the demand or cost parameters and reveals them to the firms. If in the first stage the firm and the government agreed to share information, then the government receives the information from its firm; otherwise the government remains uninformed. In stage three, governments simultaneously choose export subsidy rates. In stage four, firms observe the subsidy rates and simultaneously choose quantities or prices.

It proves useful to consider four separate cases, depending on the type of competition - prices or quantities - and the type of uncertainty - whether uncertainty is over the intercept of the common demand function or over (constant) marginal costs that affect firms individually. The first distinction is motivated by the fact that some predictions of Brander-Spencer results are sensitive to the choice of strategic variables. The second is motivated by the results in the information literature, in which the type of uncertainty - common valued or private-valued - can affect outcomes.

With demand uncertainty, we assume that firms observe the common demand intercept, so that when each firm informs its government, both governments will have identical information. With

\footnotetext{
${ }^{1}$ The effect of non-negligible setup costs is discussed in our working papers and is available from the authors.
} 
uncertainty over marginal costs, we assume that marginal costs fluctuate independently of each other. Further, each firm can inform only its government and only about its own cost, although costs are revealed to both firms. The assumption that a firm can only inform its government is consistent with our setting in which the firm and the government must set up an institutional structure to have verifiable information disclosure. Then, the government has no means of verifying information about the foreign firm's cost supplied by its firm or by the foreign government. ${ }^{2}$ The assumption that the firm knows its rival's cost is a simplification of the idea that firms are better informed about the rivals' costs than governments; for example, it is highly likely that Toyota knows more about GM's production costs than the U.S. government. ${ }^{3}$

We now turn to our main findings. With quantity competition, firms have the incentive to disclose both demand and cost information, and governments have the incentive to receive such information. Therefore, in equilibrium governments possess complete information as assumed in the strategic trade policy literature. With price competition, governments still value information from firms but firms have no incentives to disclose information. Therefore, governments remain uninformed in equilibrium.

Further, with quantity competition and demand uncertainty, the equilibrium outcome is a prisoner's dilemma. Although each government gets informed, each country's welfare would be greater, should governments jointly commit to not receiving information from the firms. While a prisoner's dilemma is also a feature of the Brander-Spencer model, the two are distinct. There it arises from governments' inability to commit to not subsidizing exports, but here governments always

\footnotetext{
2 The United States has been unsuccessful at getting OECD nations to share information regarding their "market window" activity (essentially, government supported financing, Ex-Im Bank 2005), which suggests that countries also would not share firm information. In addition, (see footnote 5), firms have opposed the intergovernmental sharing of information.

${ }^{3}$ This structure is also assumed in the contracting literature with uncertainty. For example, in the principle-agent problem examined by Fershtman and Judd (1997, p. 929), each firm manager knows the other firm's manager's costs and demand, but the owners do not have this information when setting the contract.
} 
intervene, and the prisoner's dilemma arises from governments' lack of commitment to not receiving information. For this reason, we call ours an informational prisoner's dilemma.

But would firms really disclose information to the governments? And how do they commit to an agreement to disclose information over a long haul? Surprisingly, firms disclose a good deal of information to the governments in exchange for the subsidies. As a well-known example, the U.S. Export-Import Bank, a classic illustration of how governments subsidize trade, requires both demand and cost information from any applicant. Specifically, for its large aircraft subsidy the Export-Import Bank's requirements include, inter alia, operating statistics for the airline for at least the past three years including load factors, yield (passenger and cargo), aircraft utilization rates, passenger revenue, tonnage revenue, and operating expenses "for each geographic region or route type and each business segment." Projected balance sheet, income, and cash flow statements for a 5 -year period must also be submitted ${ }^{4}$ More generally, for any applicant the Ex-Im Bank requires, among others, financial statements, Federal tax returns and that the inventory evaluated in accordance with Generally Accepted Accounting Principles. ${ }^{5}$

One prediction of our model - in fact, that of the Brander and Spencer (1985) model more generally - is that subsidies are correlated with demand. We also see this in the Ex-Im Bank's aircraft subsidy case. First, the conditions to receive the credit imply that, all else equal, applicants are more likely to get the credit, the higher demand for the airplanes (e.g., greater passenger and tonnage revenue). Second, the Ex-Im Bank (2005) has noted this relationship: "[The] 2003's rebound of

\footnotetext{
${ }^{4}$ See www.exim.gov. Other requirements include audited balance sheet, income, cash flow statements and annual reports for the three most recent fiscal years, and interim statements for the most recent period. Annual statements must be prepared in accordance with internationally accepted accounting principles and audited in accordance with international standards.

${ }^{5}$ There is also ancillary evidence that the disclosed information is truthful, as firms can be adamant that the information disclosed should not be shared. For example, the National Customs Brokers and Forwarders Association of America is opposed to a plan by the Department of Commerce and the U.S. Census Bureau to disclose export data as part of the war on terrorism, "warning that more widespread, detailed, export data sharing could damage U.S. trade" (Edmonson, 2004).
} 
increasing official export credit volumes by the G-7 continued in 2004, a reflection of the general global increase in demand for goods and services." An implication of this is that there is greater variability of profits with the subsidies than without, which appears in our derivations.

Our results provide some insight in the works of Qiu (1994) and Maggi (1999) on the effect of asymmetric uncertainty on strategic trade policy. ${ }^{6}$ Qiu (1994) has compared the effect of completeinformation (separating) and incomplete-information (pooling) export subsidies in the environment in which only one government is active and in which a firm's cost is unknown to both its government and its rival firm. For quantity competition, he finds that the government prefers to be informed and thus offers complete-information subsidies (contracts). However, the effects of price competition and demand uncertainty, which we examine, are unresolved. ${ }^{7}$ Further, with only one active government, the prisoner's dilemma aspect is not revealed. One interesting aspect in Qiu (1994) is that the separating contract informs both the home government and the rival firm. However, the welfare implications of these two effects are not separated. By focusing on government learning, we are able to disentangle the two effects.

Maggi (1999) has examined the effect of uncertainty over a common parameter (demand or cost) for quantity competition with two active governments. The key result is that, as governments offer nonlinear export subsidies to have the firms reveal information (their types), the firms respond by expanding outputs, thereby exacerbating the Brander-Spencer prisoner's dilemma. Since Maggi (1999) considers only export subsidies that reveal information, his result amalgamates two effects: one to give firms the strategic advantage and one to extract information. By examining firms' and governments' incentives separately, our results can disentangle these two effects.

\footnotetext{
${ }^{6}$ Brainard and Martimort (1996) also present a model in which they discuss the role of contracts to extract information from firms. However, Maggi (1998) proves that their equilibrium does not exist.

${ }^{7}$ It has been pointed out (Okajima 2003, Qiu 2003) that in price competition there is no separating equilibrium in Qiu (1994) so the price competition case cannot be analyzed.
} 
The remainder of the paper is organized in four sections. In section 2 we examine the case of quantity competition with unknown demand (section 2.A) and unknown costs (section 2.B). In Section 3 we turn to price competition, examining both unknown demand (section 3.A) and unknown costs (section 3.B). Section 4 relaxes some key assumptions of the model. Section 5 summarizes the findings and discusses related issues. The appendix contains the proofs of the lemmas and propositions presented in the text.

\section{Quantity competition}

For quantity competition, assume that firms produce homogeneous goods at constant marginal costs $\mathrm{c}_{\mathrm{i}}(\mathrm{i}=1,2)$ and face linear (inverse) demand $\mathrm{p}=\mathrm{A}-\mathrm{q}_{1}-\mathrm{q}_{2}$, where $\mathrm{q}_{\mathrm{i}}$ denotes export sales for firm $i=1,2$. To begin with, consider the Brander-Spencer model, in which each government sets subsidy $\mathrm{s}_{\mathrm{i}}$ to maximize domestic welfare $\mathrm{w}_{\mathrm{i}}$, knowing that firms will observe the subsidy rates and then choose quantities to maximize profits $\pi_{\mathrm{i}}$. In equilibrium, government i subsidizes its firm at the rate

$$
\mathrm{s}_{\mathrm{i}}^{\mathrm{bs}}=\left(\mathrm{A}-3 \mathrm{c}_{\mathrm{i}}+2 \mathrm{c}_{\mathrm{j}}\right) / 5,
$$

while firm $i$ earns the profit

$$
\pi_{\mathrm{i}}^{\mathrm{bs}}=(4 / 25)\left(\mathrm{A}-3 \mathrm{c}_{\mathrm{i}}+2 \mathrm{c}_{\mathrm{j}}\right)^{2}=\left(\mathrm{q}_{\mathrm{i}}^{\mathrm{bs}}\right)^{2}
$$

with domestic welfare that equals

$$
\mathrm{w}_{\mathrm{i}}^{\mathrm{bs}}=(2 / 25)\left(\mathrm{A}-3 \mathrm{c}_{\mathrm{i}}+2 \mathrm{c}_{\mathrm{j}}\right)^{2}
$$

where the superscript obviously stands for "Brander-Spencer."

\section{A. Demand uncertainty and quantity competition}

Begin with demand uncertainty. Assume that the demand intercept $\mathrm{A}$ is distributed with mean $\overline{\mathrm{A}}$ and variance $\sigma^{2}(\mathrm{~A})$. The distribution is such that outputs are always positive in equilibrium. 


\section{A.1. The fourth-stage game}

In the fourth stage, firms know the value of $\mathrm{A}$ and the subsidy rates, and hence play a game of complete information as in the Brander-Spencer model. In equilibrium, firm $i$ exports the quantity

$$
\mathrm{q}_{\mathrm{i}}^{*}(\mathrm{~A})=\left(\mathrm{A}-2 \mathrm{c}_{\mathrm{i}}+2 \mathrm{~s}_{\mathrm{i}}+\mathrm{c}_{\mathrm{j}}-\mathrm{s}_{\mathrm{j}}\right) / 3
$$

and earns the profit

$$
\pi_{\mathrm{i}}^{*}(\mathrm{~A})=\left(\mathrm{A}-2 \mathrm{c}_{\mathrm{i}}+2 \mathrm{~s}_{\mathrm{i}}+\mathrm{c}_{\mathrm{j}}-\mathrm{s}_{\mathrm{j}}\right)^{2} / 9
$$

These equilibrium quantities and profits vary with realizations of the demand intercept $\mathrm{A}$.

\section{A.2. The third-stage game}

In the third stage, governments simultaneously choose subsidy rates. There are three cases to consider; two symmetric cases in which both governments are informed or neither is informed, and one asymmetric case in which only one is informed. When neither government is informed, the game between governments is one of two-sided incomplete information, so we look for the Bayesian-Nash equilibrium. Each government maximizes ex ante national welfare:

$$
\mathrm{E}\left[\mathrm{w}_{\mathrm{i}}(\mathrm{A})\right]=\mathrm{E}\left[\pi_{\mathrm{i}}^{*}(\mathrm{~A})-\mathrm{si}_{\mathrm{i}}{ }^{*}(\mathrm{~A})\right]
$$

where the expectations operator $\mathrm{E}($.$) is over A. Substituting from (4) and (5), we write:$

$$
E\left[w_{i}(A)\right]=\left(\bar{A}-2 c_{i}+2 s_{i}+c_{j}-s_{j}\right)^{2} / 9+\sigma^{2}(A) / 9-s_{i}\left(\bar{A}-2 c_{i}+2 s_{i}+c_{j}-s_{j}\right) / 3 .
$$

The first-order condition gives the best-response subsidy rate

$$
\mathrm{b}_{\mathrm{i}}\left(\mathrm{s}_{\mathrm{j}}\right)=\left(\overline{\mathrm{A}}-2 \mathrm{c}_{\mathrm{i}}+\mathrm{c}_{\mathrm{j}}-\mathrm{s}_{\mathrm{j}}\right) / 4 \text {. }
$$

The equilibrium subsidy rates equal

$$
\mathrm{s}_{\mathrm{i}}^{\mathrm{nn}}=\left(\overline{\mathrm{A}}-3 \mathrm{c}_{\mathrm{i}}+2 \mathrm{c}_{\mathrm{j}}\right) / 5
$$

where superscripts (nn) indicates that neither government is informed. These subsidy rates depend on the mean of the demand intercept, $\overline{\mathrm{A}}$, but not on its actual realization. 
Observe that $\mathrm{s}_{\mathrm{i}}^{\mathrm{nn}}$ are identical to $\mathrm{s}_{\mathrm{i}}^{\mathrm{bs}}$ from the Brander-Spencer model when the latter is evaluated at $\overline{\mathrm{A}}$. This is not surprising because, when the distribution of the demand intercept becomes degenerate at $\overline{\mathrm{A}}$, the present model converges to the Brander-Spencer model.

Substituting $\mathrm{s}_{\mathrm{i}}^{\mathrm{nn}}$ into the profit function gives firm i's realized profit.

$$
\pi_{\mathrm{i}}^{\mathrm{nn}}(\mathrm{A})=\left(5 \mathrm{~A}+\overline{\mathrm{A}}-18 \mathrm{c}_{\mathrm{i}}+12 \mathrm{c}_{\mathrm{j}}\right)^{2} / 225 .
$$

Taking expectations over A yields the equilibrium expected profit

$$
\mathrm{E}\left[\pi_{\mathrm{i}}^{\mathrm{nn}}(\mathrm{A})\right]=\pi_{\mathrm{i}}^{\mathrm{bs}}(\overline{\mathrm{A}})+\sigma^{2}(\mathrm{~A}) / 9
$$

where $\pi_{\mathrm{i}}^{\mathrm{bs}}(\overline{\mathrm{A}})$ equals $\pi_{\mathrm{i}}^{\mathrm{bs}}$ evaluated at $\mathrm{A}=\overline{\mathrm{A}}$. Since $\sigma^{2}(\mathrm{~A})$ is positive, (7) implies that ex ante equilibrium profits are greater with uncertainty. The gains arise from the mean-preserving spread of the distribution of the demand intercept and from convexity of the profit function with respect to the demand intercept.

Further substitution yields the equilibrium expected welfare:

$$
\mathrm{E}\left[\mathrm{w}_{\mathrm{i}}^{\mathrm{nn}}(\mathrm{A})\right]=\mathrm{w}_{\mathrm{i}}^{\mathrm{bs}}(\overline{\mathrm{A}})+\sigma^{2}(\mathrm{~A}) / 9,
$$

where $w_{i}^{b s}(\bar{A})$ is the equilibrium welfare from the Brander-Spencer model evaluated at $A=\bar{A}$. Expected welfare also is greater with uncertainty because of convexity of the welfare function. Notice that the gains from uncertainty in profit and welfare are identical, as governments do not react to realizations of A.

In the case with only one informed government, the third-stage game is one of one-sided incomplete information. Assume that government 1 is informed. Government 1 then knows the value of the demand parameter and maximizes:

$$
\mathrm{w}_{1}(\mathrm{~A})=\pi_{1} *(\mathrm{~A})-\mathrm{s}_{1} \mathrm{q}_{1} *(\mathrm{~A}),
$$

where $\mathrm{q}_{1} *(\mathrm{~A})$ and $\pi_{1} *(\mathrm{~A})$ are given in (4) and (5). The optimal (best-response) subsidy rate is 


$$
\mathrm{b}_{1}(\mathrm{~A})=\left(\mathrm{A}-\mathrm{c}_{1}+\mathrm{c}_{2}-\mathrm{s}_{2}\right) / 4
$$

Government 2 is uninformed and maximizes ex ante welfare as before, with the best-response subsidy rate in (6). Solving the two best-response functions as well as calculating each government's expectation of the other's best-response function based on (6) and (8), and the other's expectation of its own best-response function, we obtain the equilibrium subsidy rates: ${ }^{8}$

$$
\begin{aligned}
& \mathrm{s}_{1}{ }^{\mathrm{cn}}(\mathrm{A})=\left(5 \mathrm{~A}-\overline{\mathrm{A}}-12 \mathrm{c}_{1}+8 \mathrm{c}_{2}\right) / 20 \\
& \mathrm{~s}_{2}{ }^{\mathrm{nc}}=\left(\overline{\mathrm{A}}-3 \mathrm{c}_{2}+2 \mathrm{c}_{1}\right) / 5,
\end{aligned}
$$

where the superscript "cn" indicates that the government in question has complete (c) information while the other government is not informed (n); the superscript "nc" reverses the order. These expressions show clearly that government 1 can, and government cannot, attune export subsidies to a realization of $\mathrm{A}$.

Substituting the above subsidy rates into the profit functions, we obtain the equilibrium profits:

$$
\begin{aligned}
& \pi_{1}{ }^{\mathrm{cn}}(\mathrm{A})=\left(5 \mathrm{~A}-\overline{\mathrm{A}}-12 \mathrm{c}_{1}+8 \mathrm{c}_{2}\right)^{2} / 100 \\
& \pi_{2}{ }^{\mathrm{nc}}(\mathrm{A})=\left(5 \mathrm{~A}+3 \overline{\mathrm{A}}-24 \mathrm{c}_{2}+16 \mathrm{c}_{1}\right)^{2} / 400 .
\end{aligned}
$$

Straightforward calculation yields the equilibrium welfare levels

$$
\begin{aligned}
& \mathrm{w}_{1}{ }^{\mathrm{cn}}(\mathrm{A})=\left(5 \mathrm{~A}-\overline{\mathrm{A}}-12 \mathrm{c}_{1}+8 \mathrm{c}_{2}\right)^{2} / 200 \\
& \mathrm{w}_{2}{ }^{\mathrm{nc}}(\mathrm{A})=\left(5 \mathrm{~A}-29 \overline{\mathrm{A}}+72 \mathrm{c}_{2}-48 \mathrm{c}_{1}\right)\left(5 \mathrm{~A}-17 \overline{\mathrm{A}}+36 \mathrm{c}_{2}-24 \mathrm{c}_{1}\right) / 3600+\sigma^{2}(\mathrm{~A}) / 9 .
\end{aligned}
$$

Taking expectations yields the ex ante equilibrium profits and welfare:

$$
\begin{aligned}
& \mathrm{E}\left[\pi_{1}{ }^{\mathrm{cn}}(\mathrm{A})\right]=\pi_{1}{ }^{\mathrm{bs}}(\overline{\mathrm{A}})+\sigma^{2}(\mathrm{~A}) / 4 \\
& \mathrm{E}\left[\pi_{2}{ }^{\mathrm{nc}}(\mathrm{A})\right]=\pi_{2}{ }^{\mathrm{bs}}(\overline{\mathrm{A}})+\sigma^{2}(\mathrm{~A}) / 16 .
\end{aligned}
$$

\footnotetext{
${ }^{8}$ A simple way to derive this is to note, starting from the incomplete information equilibrium, that a change in A affects government 1's subsidy linearly and so government 1's expected subsidy does not change.
} 


$$
\begin{aligned}
& \mathrm{E}\left[\mathrm{w}_{1}{ }^{\mathrm{cn}}(\mathrm{A})\right]=\mathrm{w}_{1}{ }^{\mathrm{bs}}(\overline{\mathrm{A}})+\sigma^{2}(\mathrm{~A}) / 8 \\
& \mathrm{E}\left[\mathrm{w}_{2}{ }^{\mathrm{nc}}(\mathrm{A})\right]=\mathrm{w}_{2}{ }^{\mathrm{bs}}(\overline{\mathrm{A}})+\sigma^{2}(\mathrm{~A}) / 16 .
\end{aligned}
$$

Note that the welfare gains from uncertainty are half the size of those in profit when a government can react to realizations of $\mathrm{A}$, but they are identical if a government cannot.

Using equations (7) and (9) - (13), we can state the effect of government learning on profit and welfare when the rival government does not learn. (We drop country subscripts in stating all our lemmas and propositions.)

\section{Lemma 1. With uncertain demand and quantity competition:}

(i) The firm and the government have the incentive to share information, if the rival pair does not; i.e., $E\left[\pi^{c n}(A)\right]>E\left[\pi^{n n}(A)\right]$ and $E\left[w^{c n}(A)\right]>E\left[w^{n n}(A)\right]$

(ii) The firm and the government not sharing information are harmed if the rival pair shares information; i.e., $E\left[\pi^{n c}(A)\right]<E\left[\pi^{n n}(A)\right]$ and $E\left[w^{n c}(A)\right]<E\left[w^{n n}(A)\right]$.

The intuition for part (i) is as follows. An informed government raises the subsidy rate when demand is higher and lowers it when demand is lower. Thus, informing the government turns good news (high demand) into even greater profits for the firm, while bad news (low demand) results in even smaller profits. But equilibrium profits are increasing and convex in A and the subsidy rate. Further, the subsidy rate is linear and increasing in A. Therefore, disclosing information makes the firm's profit function more convex in A, and increases its ex ante profit. As for welfare, since the firm exports more when demand is high, increasing the subsidy at high demands causes more profit shifting from the rival firm. Although there is less profit shifting at lower demands, profits are lower then anyway. Therefore, the losses suffered at lower demands are outweighed by the gains realized at times of higher demands. 
Thus, adjusting the subsidy to demand makes the welfare function more convex, and raises domestic welfare. This profit shifting also drives part (ii) of the lemma.

The validity of the above argument does not depend on whether government 2 is informed or uninformed. To see this, consider the third case, in which both governments are informed. In this case, the third-stage game is one of complete information as in the Brander-Spencer model. Taking expectations of (2) and (3) over A yields the expected values:

$$
\begin{aligned}
& \mathrm{E}\left[\pi_{\mathrm{i}}^{\mathrm{cc}}(\mathrm{A})\right]=\pi_{\mathrm{i}}^{\mathrm{bs}}(\overline{\mathrm{A}})+4 \sigma^{2}(\mathrm{~A}) / 25 \\
& \mathrm{E}\left[\mathrm{w}_{\mathrm{i}}^{\mathrm{cc}}(\mathrm{A})\right]=\mathrm{w}_{\mathrm{i}}^{\mathrm{bs}}(\overline{\mathrm{A}})+2 \sigma^{2}(\mathrm{~A}) / 25
\end{aligned}
$$

where the superscript "cc" indicates that both governments have complete information. The next lemma follows immediately from (10) - (15).

\section{Lemma 2. With uncertain demand and quantity competition:}

(i) The firm and the government have the incentive to share information, when the rival pair does; i.e., $E\left[\pi^{c c}(A)\right]>E\left[\pi^{n c}(A)\right]$ and $E\left[w^{c c}(A)\right]>E\left[w^{n c}(A)\right]$.

(ii) The firm and the government sharing information are harmed when the rival pair shares information; i.e., $E\left[\pi^{c n}(A)\right]>E\left[\pi^{c c}(A)\right]$ and $E\left[w^{c n}(A)\right]>E\left[w^{c c}(A)\right]$.

\section{A.3. The first stage}

In the first stage of the game, the firm and the government in each country simultaneously and independently decide whether to enter into an agreement to share information. Assuming negligible setup and verification costs, lemmas 1 and 2 imply that disclosing information is the dominant strategy for each firm and that receiving information is the dominant strategy for each government. Hence, governments obtain complete information as assumed in the literature. 
Proposition 1: With unknown common demand and quantity competition, the game has the unique equilibrium in which both firms commit to disclosing information to their governments.

Lemmas 1 and 2 also imply that the firm and the government are harmed when the rival firm and its government share information. This point leads to the following surprising result: although each government wants to be informed, governments would be better off if they could jointly commit to not receiving information.

Proposition 2: With unknown demand and quantity competition, each country's welfare would be greater if governments jointly committed to not receiving information from their firms, i.e., $E\left[w^{c c}(A)\right]<E\left[w^{n n}(A)\right]$

The prisoner's dilemma occurs because of too much subsidy competition at high demands. This is in the spirit of the Brander-Spencer model. However, the prisoners' dilemma here is fundamentally different from that of the Brander and Spencer case. There, it arises from governments' inability to commit to not subsidizing exports, while here it is due to governments' inability to commit to not learning. For this reason, we call our version an informational prisoner's dilemma.

There is too much subsidy competition in our analysis because both governments raise subsidies at times of high demand. If uncertainty is not over a common parameter, however, policy interventions will not be perfectly correlated between governments, so subsidy competition may be mitigated, and an informational prisoner's dilemma averted. We examine this possibility in the case of unknown costs.

\section{B. Cost uncertainty and quantity competition}


Assume that (constant) marginal cost $\mathrm{c}_{\mathrm{i}}$ is distributed independently of each other, with mean $\overline{\mathrm{c}}_{\mathrm{i}}$ and variance $\sigma^{2}\left(c_{i}\right)(i=1,2)$ while the demand parameter $A$ is fixed. For ease, assumed symmetric variance; i.e., $\sigma^{2}\left(c_{1}\right)=\sigma^{2}\left(c_{2}\right) \equiv \sigma^{2}$. Assume further that costs are revealed to both firms but each can only disclose its own cost, and only to its government. Section 4 relaxes these assumptions.

As the analysis follows the same steps in the previous subsection, we present only the results here, relegating the derivations to Appendix A. We begin with the following lemma:

\section{Lemma 3: With cost uncertainty and quantity competition:}

(i) The firm and the government in each country have the incentive to share information, regardless of what the rival pair does.

(ii) The firm and the government always benefit when the rival firm pair shares information.

Part (i) has a similar intuition to the one given for the previous lemmas. Here, an informed government raises the subsidy when its firm has low cost and lowers the subsidy when it has high cost. So, as in the case of unknown demand, good news for the firm (low costs) translates into even better news in the form of higher subsidies, while bad news (high costs) entails bad responses from the government. As explained earlier, this increases convexity of the profit and the welfare function, and hence disclosing information results in an increase in ex ante profit and welfare. This argument holds, whether the rival government is informed or not, which proves part (i) of lemma 3. Thus, assuming negligible verification cost, disclosing information is the dominant strategy for the firm, and receiving information is the dominant strategy for the government.

Proposition 3: When costs are unknown and quantity competition, the game has the unique 
equilibrium in which both firms commit to disclosing information to their governments.

Thus, in equilibrium governments obtain information, regardless of the type of uncertainty.

The main difference from demand uncertainty is given in part (ii) of lemma 3. With unknown costs, bad news for the foreign firm (higher than expected costs) is good news for the home firm. Further, since an informed foreign government lowers its subsidy to the foreign firm, good news (high costs for the rival) translates into better news for the home firm. Similarly, bad news (the rival having low cost) turns worse for the home firm as the foreign government raises subsidies. Given convexity, this increase in variability benefits the home firm and the home government. Thus, the home firm and its government are better off if the rival pair shares information. This argument holds, whether the home firm discloses information or not, which proves part (ii) of lemma 3.

Since the firm and the government in each country choose to share information in equilibrium, and want the rival pair to do the same, part (ii) of lemma 3 implies that there is no informational prisoner's dilemma with quantity competition and unknown costs.

\section{Proposition 4: When costs are unknown and firms compete in quantities, there is no informational prisoner's dilemma, i.e., $E\left[w^{c c}(c)\right]>E\left[w^{n n}(c)\right]$.}

To sum this section, with quantity competition and negligible verification costs, firms have the incentive to disclose both demand and cost information to governments while governments have the incentive to receive demand and cost information. Hence, in equilibrium governments are informed as assumed in the standard strategic trade policy literature. However, given the sensitivity to the type of competition of some results of oligopoly models, it would be interesting to see how the above results 
will be affected by price competition.

\section{Price competition}

Following the literature [e.g., Eaton and Grossman (1986)], we assume that price-setting firms produce differentiated goods and, by the appropriate choice of units, write demand for good $\mathrm{i}$ as

$$
\mathrm{q}_{\mathrm{i}}=\alpha-\mathrm{p}_{\mathrm{i}}+\delta \mathrm{p}_{\mathrm{j}}
$$

where $\delta(0<\delta<1)$ measures the degree of product differentiation between the two goods.

\section{A. Price competition and demand uncertainty}

We begin with the case of unknown demand, where the common demand intercept $\alpha$ is assumed to vary with mean $\bar{\alpha}$ and variance $\sigma^{2}(\alpha)$. To simplify the exposition, assume in this subsection that the firms have identical constant marginal costs $\mathrm{c}$. As the analysis is similar to the one in the previous section, we present only the results, with the derivations in Appendix B.

As is well known, with price competition, the optimal policy intervention is an export tax (Grossman and Eaton 1985). Further, an informed government raises export tax at times of high demand and lowers tax at times of low demand. Therefore, with an informed government, good news (high demand) turns less good, and band news (low demand) turns less bad for the firm. Since export volumes are greater when demand is higher, this makes the profit function less convex, thereby reducing the firm's ex ante profit. Therefore, with price competition firms prefer not to disclose information to the governments. However, since policy intervention is more effective with higher demand and export volumes, the welfare function becomes more convex when a government intervenes with complete information. Thus, each government still wants to receive information.

Further, since an informed government penalizes its firm at high demand, good news (high 
demand) turns into even better news for the rival firm. Although the opposite result holds at low demand, the loss at low demand is outweighed by the gains accruing at high demand. Thus, disclosing information benefit the rival firm and the rival government. These arguments hold, regardless of the rival government's information. We summarize these results in the next lemma.

\section{Lemma 4: With uncertain demand and price competition,}

(i) Firms have no incentive to disclose information, although governments want to be informed;

(ii) The firm and the government are always better off if the rival firm discloses information.

Since not disclosing information to the government is a firm's dominant strategy by part (i) of lemma 4, in equilibrium the government remains uninformed. Thus, verification costs are irrelevant for the next result.

Proposition 5: With unknown demand and price competition, the model has the unique equilibrium, in which neither firm commits to disclosing information with its government.

Thus, the governments remain uninformed in equilibrium. However, since a government has an incentive to get informed, regardless of what the other government does, each government could induce the firm to enter into an agreement to reveal information by providing additional upfront fixed subsidies, and welfare will be greater. In other words, there is no informational prisoner's dilemma here. We summarize these results in the next proposition.

Proposition 6: With unknown demand and price competition, each country's welfare would increase if both governments get informed, i.e., $E\left[w^{c c}(\alpha)\right]>E\left[w^{n n}(\alpha)\right]$. 


\section{B. Price competition and cost uncertainty}

We now examine the case of unknown costs when firms compete in prices. As in the case of quantity competition, assume that costs $c_{i}$ are distributed independently, with mean $\overline{c_{i}}$ and common variance $\sigma^{2}(\mathrm{c})$. Further, assume that each firm can only disclose its cost to its government, though it is informed of both costs. As before, we present the results, with the derivations in Appendix C.

In the present case, most results are the same as those from the preceding subsection. In particular, profits always decrease when a firm discloses information. The main difference from the case of unknown demand is that the firm and the government would be harmed if the rival firm discloses information to its government. In this respect, the present case is similar to the case of quantity competition with unknown demand. The next lemma states these key results.

\section{Lemma 5. With uncertain cost and price competition,}

(i) Firms have no incentive to disclose information, although governments want to be informed;

(ii) The firm and the government in each country will be worse off if the rival pair shares information.

By part (i), not disclosing information is the dominant strategy for firms. Thus, in price competition governments do not get informed.

Proposition 7: With unknown costs and price competition, the model has the unique equilibrium, in which neither firm commits to disclosing information to its government.

Governments still have incentives to unilaterally obtain information. Therefore, if additional 
upfront fixed subsidies are available, both governments can still get informed. If both succeed in getting informed, however, an informational prisoner's dilemma arises once again.

\section{Proposition 8: With unknown costs and price competition, governments would be worse off if they jointly received information, i.e., $E\left[w_{i}^{c c}(c)\right]<E\left[w_{i}^{n n}(c)\right]$.}

\section{Extensions}

In the case of cost uncertainty we assumed that costs are revealed to both firms but each firm can inform only its cost to its government. Since firm-specific costs are private, however, a rich taxonomy of cases can arise, depending on what firms learn and what information they can pass and to whom. In this section we examine the effect of alternative assumptions in the information structure as well as the effect of asymmetric cost variance.

For the most part, variations in the information structure have little effect on our results. ${ }^{9}$ With quantity competition, in particular, propositions 3 and 4 continue to hold. That is, for negligible verification costs, the government and the firm in each country still benefit from sharing information. ${ }^{10}$ And there is no informational prisoner's dilemma, as each country is better off when both firms disclose information than when neither firm does. With price competition, variations in the information structure lead to some interesting differences in government's incentives, but not on firms' incentives. Thus, in equilibrium governments remain uninformed.

With this in mind, begin with the case of asymmetry in variance. To develop the intuition of what this asymmetry entails, suppose that firm 1's cost has zero variance - it is constant at the mean.

\footnotetext{
${ }^{9}$ The calculations for the results of this section are available on request from the authors.

${ }^{10}$ It is not surprising in light of a standard result in the information sharing literature (see, e.g., Vives 1990) which reinforces the effect here: a firm would enter into an ex ante agreement to disclose cost information with its rival. This in part drives the results found in Qiu (1994),
} 
Then, there is no learning for government 1 , so if government 2 induces firm 2 to disclose cost information, by lemma 5 government 2 will be better off but government 1 will be harmed. More generally, if $\sigma^{2}\left(c_{1}\right)<2 \sigma^{2}\left(c_{2}\right)$, government 2 benefits from both firms disclosing, while government 1 is harmed. This is essentially a restatement of the prisoner's dilemma (proposition 8): a government benefits from learning its firm's cost, but is harmed if the rival government learns (and the harm is greater than its benefit).

Consider next the case of information leakages; once a firm discloses information to its government, the rival government also obtains the same information. In such cases, a government is made worse off when its firm discloses information, as the gain from learning its firm's cost is less than the loss from the rival government learning it. ${ }^{11}$ Hence, each government has an incentive to keep the information secret. ${ }^{12}$ At the same time, firms' incentives are the same as before: they do not want to disclose information. More generally, firms never like any government learning any firm's costs. Thus, in equilibrium neither firm discloses information, so governments are uninformed, as in the preceding analysis.

Finally, consider the case in which firms initially do not know each other's cost. In this case, suppose, as in Qiu (1994), that disclosing information to its government also informs the rival firm. Then, it is still the dominant strategy for a firm not to disclose information to its government. ${ }^{13}$ Furthermore, as with information leakage cases, governments no longer want firms to disclose information. ${ }^{14}$ Thus, again in equilibrium neither firm discloses information to the government. The

\footnotetext{
${ }^{11}$ Generally, a government does not want its rival government to learn either firm's costs. This may partly explain the resistance to the information sharing noted in footnote 3 .

${ }^{12}$ This contrasts with quantity competition, in which the government benefits from the rival government learning.

${ }^{13}$ Further, firms prefer neither firm disclosing to both firms disclosing information, unless the cost variances differ substantially. For example, if $\sigma^{2}\left(c_{1}\right)<<\sigma^{2}\left(c_{2}\right)$, then firm 1 prefers both firms disclosing to neither firm disclosing, because the gain from learning the rival's cost outweighs the loss from its cost being learnt. Firm 2 still prefers neither firm disclosing.

${ }^{14}$ If $\sigma^{2}\left(c_{1}\right) \ll<\sigma^{2}\left(c_{2}\right)$, however, government 1 may prefer both firms disclosing to neither firm disclosing.
} 
presence of information leakages between governments does not change these results.

To sum up, variations in the information structures have no effect on the firms' incentives. In particular, firms engaged in price competition do not want to disclose information, so governments remain uninformed in equilibrium. The main difference is that, except in cases of an extreme asymmetry, governments are also worse off if they both get informed. Thus, the informational prisoner's dilemma noted in proposition 8 may not arise.

\section{Summary}

In this paper we re-examine the standard assumption in the strategic trade literature that governments have complete information about the economy. Assuming instead that only firms obtain cost and market information, we examine when they have incentives to disclose information to the governments so that the standard assumption in the literature is reasonable. Our model adopts the Brander-Spenser setting, in which two firms compete in a third-country market, and proceeds in four stages. First, the firm and the government in each country simultaneously decide whether to enter into an ex ante agreement to share information. Then, nature reveals the values of the demand intercept or marginal costs to the firms, but not to the governments. The firm discloses the information to its government only if the two entered into an information-sharing agreement in the first stage. In the third stage, governments simultaneously choose export subsidy rates. In the final stage, firms compete in quantities or prices.

The adjacent table gives a bird's-eye view of the effect of a firm's decision to disclose information. A firm's decision to disclose information depends on the type of competition - quantity or price - but not on the type of uncertainty - common demand or firm-specific costs. Specifically, a firm does not want to commit to disclosing information when engaged in price competition. In contrast, 
governments always benefits from being informed, regardless of the rival government's decision. These results are utilized to yield our main findings summarized below.

$<$ Please Insert Table 1 Around Here. $>$

With quantity competition, firms have incentives to disclose information, whether uncertainty is over the demand intercept or marginal costs. Since governments always welcome information, in equilibrium governments become informed, provided that verifications are negligible. With price competition, however, firms refuse to disclose information, so governments remain uninformed in equilibrium. These basic results hold, regardless of whether firms learn or do not learn the rival's cost, whether they pass information about the rival's cost to governments, or whether there are information leakages between governments. The upshot is that our analysis validates the assumption of informed governments for quantity competition cases but not for price competition cases.

The above table also helps us connect our results to the related works of Qiu (1994) and Maggi (1999) discussed earlier. Studying the case of firm-specific cost uncertainty in quantity competition (the top right-hand box of the table), Qiu (1994) showed that the government prefers the separating equilibrium to the pooling equilibrium; that is, the government gets information from the firm. In his analysis only one government is active, and separating subsidies (contracts) disclose the home firm's cost to the rival as well as to the home government. Our model indicates that this result extends to the case of two active governments. Our analysis shows further that in the case of price competition the firm is harmed by revealing information to its government. This finding is consistent with the nonexistence of the separating equilibrium for price competition in Qiu (1994).${ }^{15}$ More interestingly, with bilateral intervention there is an informational prisoner's dilemma; while each government would prefer learning (and hence separating contracts if they existed), governments would be made worse off

\footnotetext{
${ }^{15}$ See Okajima (2003) and Qiu (2003).
} 
if they both get firms to reveal information.

Maggi (1999) compared the equilibrium with and without demand uncertainty under nonlinear subsidies (contracts) both in quantity and price competition (the two left-hand boxes of the table), and found that demand uncertainty exacerbates the prisoner's dilemma inherent in the Brander-Spencer model. When the government's policy is limited to linear subsidies, however, our analysis shows that profits and welfare are always higher with uncertainty, regardless of the type of competition and the type of uncertainty.

The Brander-Spencer model has been extended to the cases of domestic consumption, multiple national firms and multiple national industries and in many other directions. ${ }^{16}$ It would be interesting to re-examine all such models by assuming, as we did here, that governments must get information from firms. While we leave such extensions for future work, we believe that the effects found here will play an important role and the basic effects will remain intact in such extensions. Consider, for example, what would occur if each country has multiple firms. ${ }^{17}$ If firms compete in prices, then a high (low) cost still leads to a low (high) tax rate, thereby reducing the convexity in profits. So, firms will have no incentive to disclose information, as in our analysis. If firms compete in quantities, then government intervention will still increase the convexity of the profit function of each firm, thereby inducing government learning in equilibrium.

A second direction our research could take would be to explore further the effects of asymmetry in uncertainty. In particular, the case of cost uncertainty could lead to additional results under different informational structures. For example, if a firm faces almost no uncertainty over its cost while there is a great deal of uncertainty over the rival's cost, then in price competition a firm might

\footnotetext{
${ }^{16}$ See Brander (1995) for a survey of extensions to the Brander-Spencer model.

${ }^{17}$ This is assuming that the cost heterogeneity among firms is not too large: otherwise, firms with sufficiently high marginal costs might be driven out of the market. See Lahiri and Ono (1997) who show that this could be welfare improving when firms compete in quantities.
} 
like to inform both governments, while its rival would not. Finally, these two broad extensions could be combined to examine, for instance, the case of multiple firms in each country, which are heterogeneous both in costs and in the degree of uncertainty. 


\section{Appendix A: Derivations for quantity competition and unknown costs (section 3.B)}

Let $\mathrm{c} \equiv\left(\mathrm{c}_{1}, \mathrm{c}_{2}\right)$. The expressions for the stage-four equilibrium quantity $\mathrm{q}_{\mathrm{i}}^{*}(\mathrm{c})$ and profit $\pi_{\mathrm{i}}^{*}(\mathrm{c})$ are the same as in (4) and (5) except that marginal costs are random here. In the third-stage game, with neither government informed, each government chooses a subsidy rate to maximize ex ante national welfare, which is

$$
\begin{aligned}
& E\left[w_{i}(c)\right]=E\left[\pi_{i}(c)\right]-s_{i} E\left[q_{i}(c)\right], \\
& =\left(A-2 \bar{c}_{i}+2 s_{i}+\bar{c}_{j}-s_{j}\right)^{2} / 9-s_{i}\left(A-2 \bar{c}_{i}+2 s_{i}+\bar{c}_{j}-s_{j}\right) / 3+5 \sigma^{2}(c) / 9 .
\end{aligned}
$$

The equilibrium subsidy rate $\mathrm{s}_{\mathrm{i}}^{\mathrm{nn}}$ is identical to that for the Brander-Spencer model evaluated at means; $\overline{\mathrm{c}} \equiv\left(\overline{\mathrm{c}}_{\mathrm{i}}, \overline{\mathrm{c}}_{\mathrm{j}}\right)$. Substituting $\mathrm{s}_{\mathrm{i}}^{\mathrm{nn}}$ into the profit function and taking expectations over $\mathrm{c}$, we obtain the ex ante profit

$$
\mathrm{E}\left[\pi_{\mathrm{i}}^{\mathrm{nn}}\right]=\pi_{\mathrm{i}}^{\mathrm{bs}}(\overline{\mathrm{c}})+5 \sigma^{2}(\mathrm{c}) / 9
$$

where $\pi_{\mathrm{i}}^{\mathrm{bs}}(\overline{\mathrm{c}})$ is the Brander-Spencer equilibrium profit evaluated at $\mathrm{c}=\overline{\mathrm{c}}$. The ex ante welfare is

$$
\mathrm{E}\left[\mathrm{w}_{\mathrm{i}}^{\mathrm{nn}}\right]=\mathrm{w}_{\mathrm{i}}^{\mathrm{bs}}(\overline{\mathrm{c}})+5 \sigma^{2}(\mathrm{c}) / 9
$$

where $\mathrm{w}_{\mathrm{i}}^{\mathrm{bs}}(\overline{\mathrm{c}})$ is the Brander-Spencer equilibrium welfare evaluated at $\mathrm{c}=\overline{\mathrm{c}}$.

When only government 1 is informed, government 1 does not know the foreign firm's cost, so it maximizes expected national welfare:

$$
\mathrm{E}_{2}\left[\mathrm{w}_{1}\right]=\mathrm{E}_{2}\left[\pi_{1} *\left(\mathrm{c}_{2}\right)\right]-\mathrm{s}_{1} \mathrm{E}_{2}\left[\mathrm{q}_{1} *\left(\mathrm{c}_{2}\right)\right]
$$

where expectations are taken over $\mathrm{c}_{2}$. Substituting for $\pi_{1} *\left(\mathrm{c}_{2}\right)$ and $\mathrm{q}_{1} *\left(\mathrm{c}_{2}\right)$ we have:

$$
\mathrm{E}_{2}\left[\mathrm{w}_{1}\right]=\left(\mathrm{A}-2 \mathrm{c}_{1}+2 \mathrm{~s}_{1}+\overline{\mathrm{c}}_{2}-\mathrm{s}_{2}\right)^{2} / 9-\mathrm{s}_{1}\left(\mathrm{~A}-2 \mathrm{c}_{1}+2 \mathrm{~s}_{1}+\overline{\mathrm{c}}_{2}-\mathrm{s}_{2}\right) / 3+\sigma^{2} / 9
$$

The first-order condition gives the best response function 


$$
\mathrm{b}_{1}\left(\mathrm{~s}_{2}\right)=\left(\mathrm{A}-2 \mathrm{c}_{1}+\overline{\mathrm{c}}_{2}-\mathrm{s}_{2}\right) / 4
$$

For government 2, which is uninformed, the best-response function is written

$$
\mathrm{b}_{2}\left(\mathrm{~s}_{1}\right)=\left(\mathrm{A}-2 \overline{\mathrm{c}}_{2}+\overline{\mathrm{c}}_{1}-\mathrm{s}_{1}\right) / 4
$$

The equilibrium subsidy rates satisfy the two best-response functions and each government's expectation of the rival's best-response function and the rival's expectation of their own, and given by

$$
\begin{aligned}
& \mathrm{s}_{1}{ }^{\mathrm{cn}}\left(\mathrm{c}_{1}\right)=\left(2 \mathrm{~A}-5 \mathrm{c}_{1}-\overline{\mathrm{c}}_{1}+4 \overline{\mathrm{c}}_{2}\right) / 10 \\
& \mathrm{~s}_{2}{ }^{\mathrm{nc}}=\left(\mathrm{A}-3 \overline{\mathrm{c}}_{2}+2 \overline{\mathrm{c}}_{1}\right) / 5 .
\end{aligned}
$$

Substituting these into the profit functions and taking expectations yields the ex ante expressions:

$$
\begin{aligned}
& \mathrm{E}\left[\pi_{1}{ }^{\mathrm{cn}}\right]=\pi_{1}{ }^{\mathrm{bs}}(\overline{\mathrm{c}})+10 \sigma^{2}(\mathrm{c}) / 9 \\
& \mathrm{E}\left[\pi_{2}^{\mathrm{nc}}\right]=\pi_{2}^{\mathrm{bs}}(\overline{\mathrm{c}})+25 \sigma^{2}(\mathrm{c}) / 36 \\
& \mathrm{E}\left[\mathrm{w}_{1}{ }^{\mathrm{cn}}\right]=\mathrm{w}_{1}{ }^{\mathrm{bs}}(\overline{\mathrm{c}})+11 \sigma^{2}(\mathrm{c}) / 18 \\
& \mathrm{E}\left[\mathrm{w}_{2}{ }^{\mathrm{nc}}\right]=\mathrm{w}_{2}{ }^{\mathrm{bs}}(\overline{\mathrm{c}})+25 \sigma^{2}(\mathrm{c}) / 36 .
\end{aligned}
$$

These results are used to prove the following two results:

$$
\begin{aligned}
& \mathrm{E}\left[\pi^{\mathrm{cn}}(\mathrm{c})\right]>\mathrm{E}\left[\pi^{\mathrm{nn}}(\mathrm{c})\right] \text { and } \mathrm{E}\left[\mathrm{w}^{\mathrm{cn}}(\mathrm{c})\right]>\mathrm{E}\left[\mathrm{w}^{\mathrm{nn}}(\mathrm{c})\right] . \\
& \mathrm{E}\left[\pi^{\mathrm{nc}}(\mathrm{c})\right]>\mathrm{E}\left[\pi^{\mathrm{nn}}(\mathrm{c})\right] \text { and } \mathrm{E}\left[\mathrm{w}^{\mathrm{nc}}(\mathrm{c})\right]>\mathrm{E}\left[\mathrm{w}^{\mathrm{nn}}(\mathrm{c})\right] .
\end{aligned}
$$

When both governments are informed of the own firm's costs, each government solves the problem similar to the one confronting government 1 in the previous case. The equilibrium subsidy rates are:

$$
\mathrm{s}_{\mathrm{i}}^{\mathrm{cc}}=\left(2 \mathrm{~A}-5 \mathrm{c}_{\mathrm{i}}-\overline{\mathrm{c}}_{\mathrm{i}}+4 \overline{\mathrm{c}}_{\mathrm{j}}\right) / 10 \text {. }
$$

Substituting $\mathrm{s}_{\mathrm{i}}^{\mathrm{cc}}$ into the profit and welfare functions yields:

$$
\pi_{\mathrm{i}}^{\mathrm{cc}}(\mathrm{c})=\left(4 \mathrm{~A}-10 \mathrm{c}_{\mathrm{i}}-2 \overline{\mathrm{c}}_{\mathrm{i}}+5 \mathrm{c}_{\mathrm{j}}+3 \overline{\mathrm{c}}_{\mathrm{j}}\right)^{2} / 100
$$


Taking expectations over c yields the ex ante profit:

$$
\mathrm{E}\left[\pi_{\mathrm{i}}^{\mathrm{cc}}\right]=\pi_{\mathrm{i}}^{\mathrm{bs}}(\overline{\mathrm{c}})+5 \sigma^{2}(\mathrm{c}) / 4
$$

The expected welfare obtains straightforwardly:

$$
\mathrm{E}\left[\mathrm{w}_{\mathrm{i}}^{\mathrm{cc}}\right]=\mathrm{w}_{\mathrm{i}}^{\mathrm{bs}}(\overline{\mathrm{c}})+3 \sigma^{2}(\mathrm{c}) / 4
$$

Now, the following inequalities can be established:

$$
\begin{aligned}
& \mathrm{E}\left[\pi^{\mathrm{cc}}(\mathrm{c})\right]>\mathrm{E}\left[\pi^{\mathrm{nc}}(\mathrm{c})\right] \text { and } \mathrm{E}\left[\mathrm{w}^{\mathrm{cc}}(\mathrm{c})\right]>\mathrm{E}\left[\mathrm{w}^{\mathrm{nc}}(\mathrm{c})\right] \\
& \mathrm{E}\left[\pi^{\mathrm{cc}}(\mathrm{c})\right]>\mathrm{E}\left[\pi^{\mathrm{cn}}(\mathrm{c})\right] \text { and } \mathrm{E}\left[\mathrm{w}^{\mathrm{cc}}(\mathrm{c})\right]>\mathrm{E}\left[\mathrm{w}^{\mathrm{cn}}(\mathrm{c})\right] .
\end{aligned}
$$

Lemma 3, propositions 3 and 4 follow from (A1) - (A4).

\section{Appendix B: Derivations for price competition and unknown demand (section 4.A)}

We first present the benchmark two-stage model without uncertainty (Eaton and Grossman 1986). Straightforward calculation yields the equilibrium subsidy rate, output, profit and welfare:

$$
\begin{aligned}
& \mathrm{s}_{\mathrm{i}}^{\mathrm{eg}}=-\delta^{2}\left[(\Delta+2 \delta) \alpha-\left(\Delta-2 \delta^{2}\right) \mathrm{c}_{\mathrm{i}}+\delta(\Delta-2) \mathrm{c}_{\mathrm{j}}\right] /\left(\Delta^{2}-4 \delta^{2}\right)<0 . \\
& \mathrm{q}_{\mathrm{i}}^{\mathrm{eg}}=\left[(2+\delta) \alpha-\left(2-\delta^{2}\right)\left(\mathrm{c}-\mathrm{s}_{\mathrm{i}}\right)+\delta\left(\mathrm{c}-\mathrm{s}_{\mathrm{j}}\right)\right] / \Delta, \\
& \pi_{\mathrm{i}}^{\mathrm{eg}}=\left(\mathrm{q}_{\mathrm{i}}^{\mathrm{eg}}\right)^{2} \\
& \mathrm{w}_{\mathrm{i}}^{\mathrm{eg}}=2(\Delta-2)\left\{\left[(\Delta+2 \delta) \alpha-\left(\Delta-2 \delta^{2}\right) \mathrm{c}_{\mathrm{i}}+\delta(\Delta-2) \mathrm{c}_{\mathrm{j}}\right] /\left(\Delta^{2}-4 \delta^{2}\right)\right\}^{2} .
\end{aligned}
$$

where $\Delta=4-\delta^{2}$ and the superscripts eg stand for "Eaton-Grossman". Proceeding to our mode, with neither government informed, each government in the third stage maximizes ex ante welfare:

$$
\mathrm{E}\left[\mathrm{w}_{\mathrm{i}}(\alpha)\right]=\mathrm{E}\left[\pi_{\mathrm{i}}^{*}(\alpha)-\mathrm{s}_{\mathrm{i}} \mathrm{q}_{\mathrm{i}}^{*}(\alpha)\right]=\pi_{\mathrm{i}}^{\mathrm{eg}}(\bar{\alpha})+\mathrm{s}_{\mathrm{i}} \mathrm{q}_{\mathrm{i}}^{\mathrm{eg}}(\bar{\alpha})+\sigma^{2}\left[(\Delta-2)^{2}+\delta^{2}\right] / \Delta^{2} .
$$

The best response subsidy rate is

$$
\mathrm{b}_{\mathrm{i}}\left(\mathrm{s}_{\mathrm{j}}, \bar{\alpha}\right)=\left[2(\bar{\alpha}-\mathrm{c})-\delta\left(\bar{\alpha}+\mathrm{c}-\mathrm{s}_{\mathrm{j}}\right)-\delta^{2} \mathrm{c}\right] \delta^{2} / 4(\Delta-2)
$$

The equilibrium subsidy rates are: 


$$
\mathrm{s}_{\mathrm{i}}^{\mathrm{nn}}=\mathrm{s}_{\mathrm{i}}^{\mathrm{eg}}(\bar{\alpha})<0,
$$

Substituting the subsidy and taking the expectation yields

$$
\begin{aligned}
& \mathrm{E}\left[\pi_{\mathrm{i}}^{\mathrm{nn}}(\alpha)\right]=\pi_{\mathrm{i}}^{\mathrm{eg}}(\bar{\alpha})+\sigma^{2}(\alpha) /(2-\delta)^{2}, \\
& \mathrm{E}\left[\mathrm{w}_{\mathrm{i}}^{\mathrm{nn}}(\alpha)\right]=\mathrm{w}_{\mathrm{i}}^{\mathrm{eg}}(\bar{\alpha})+\sigma^{2}(\alpha) /(2-\delta)^{2}
\end{aligned}
$$

where $\pi_{\mathrm{i}}^{\mathrm{eg}}(\bar{\alpha})$ and $\mathrm{w}_{\mathrm{i}}^{\mathrm{eg}}(\bar{\alpha})$ are the Eaton-Grossman equilibrium profits and welfare evaluated at $\alpha=\bar{\alpha}$.

When only government 1 is informed, maximizing ex post welfare

$$
\mathrm{w}_{1}(\alpha)=\pi_{1}(\alpha)-\mathrm{s}_{1} \mathrm{q}_{1}(\alpha)
$$

for given $\alpha$ yields its best response function

$$
b_{1}\left(s_{2}, \alpha\right)=\left[2(\alpha-c)-\delta\left(\alpha+c-s_{2}\right)-\delta^{2} c\right] \delta^{2} / 4(\Delta-2)
$$

Government 2 is uninformed, so its best-response function is given in (B1), which government 1 knows. Government 2 only has the expectation of government 1's best response function, that is, $\mathrm{b}_{1}\left(\mathrm{~s}_{2}, \bar{\alpha}\right)$, which government 1 knows. The equilibrium subsidy rates are:

$$
\begin{aligned}
& \mathrm{s}_{1}{ }^{\mathrm{cn}}(\alpha)=\mathrm{s}_{\mathrm{i}}{ }^{\mathrm{eg}}(\bar{\alpha})-\delta^{2}(\alpha-\bar{\alpha})(2+\delta) /(\Delta-2)<0 \\
& \mathrm{~s}_{2}{ }^{\mathrm{nc}}=\mathrm{s}_{\mathrm{i}}{ }^{\mathrm{eg}}(\bar{\alpha})<0,
\end{aligned}
$$

Substituting these subsidies into the output equation $\mathrm{q}_{\mathrm{i}}^{\mathrm{eg}}$, and then into $\pi_{\mathrm{i}}^{\mathrm{eg}}$ and $\mathrm{w}_{\mathrm{i}}^{\mathrm{eg}}$, and finally taking expectations, we find the following ex ante values:

$$
\begin{aligned}
& \mathrm{E}\left[\pi_{1}{ }^{\mathrm{cn}}(\alpha)\right]=\pi_{\mathrm{i}}^{\mathrm{eg}}(\bar{\alpha})+\sigma^{2}(\alpha)(2+\delta)^{2} / 16 \\
& \mathrm{E}\left[\pi_{2}{ }^{\mathrm{nc}}(\alpha)\right]=\pi_{\mathrm{i}}^{\mathrm{eg}}(\bar{\alpha})+\sigma^{2}(\alpha)(\Delta+2 \delta)^{2} / 16(\Delta-2)^{2} . \\
& \mathrm{E}\left[\mathrm{w}_{1}{ }^{\mathrm{cn}}(\alpha)\right]=\mathrm{w}_{\mathrm{i}}^{\mathrm{eg}}(\bar{\alpha})+\sigma^{2}(\alpha)(2+\delta)^{2} / 8(\Delta-2) . \\
& \mathrm{E}\left[\mathrm{w}_{2}{ }^{\mathrm{nc}}(\alpha)\right]=\mathrm{w}_{\mathrm{i}}{ }^{\mathrm{eg}}(\bar{\alpha})+\sigma^{2}(\alpha)(\Delta+2 \delta)^{2} / 16(\Delta-2)^{2} .
\end{aligned}
$$


We can now establish

$$
\begin{aligned}
& \mathrm{E}\left[\pi^{\mathrm{cn}}(\alpha)\right]<\mathrm{E}\left[\pi^{\mathrm{nn}}(\alpha)\right] \text { and } \mathrm{E}\left[\mathrm{w}^{\mathrm{cn}}(\alpha)\right]>\mathrm{E}\left[\mathrm{w}^{\mathrm{nn}}(\alpha)\right] \\
& \mathrm{E}\left[\pi^{\mathrm{nc}}(\mathrm{c})\right]>\mathrm{E}\left[\pi^{\mathrm{nn}}(\mathrm{c})\right] \text { and } \mathrm{E}\left[\mathrm{w}^{\mathrm{nc}}(\mathrm{c})\right]>\mathrm{E}\left[\mathrm{w}^{\mathrm{nn}}(\mathrm{c})\right]
\end{aligned}
$$

When both governments are informed, it is essentially the Eaton and Grossman case. The equilibrium ex ante profit and welfare are:

$$
\begin{aligned}
& \mathrm{E}\left[\pi_{\mathrm{i}}^{\mathrm{cc}}(\alpha)\right]=\pi_{\mathrm{i}}^{\mathrm{eg}}(\bar{\alpha})+\sigma^{2}(\alpha)[(\Delta-2) /(\Delta-2 \delta)]^{2} . \\
& \mathrm{E}\left[\mathrm{w}_{\mathrm{i}}^{\mathrm{cc}}(\alpha)\right]=\mathrm{w}_{\mathrm{i}}^{\mathrm{eg}}(\bar{\alpha})+2 \sigma^{2}(\alpha)(\Delta-2) /(\Delta-2 \delta)^{2} .
\end{aligned}
$$

We now have

$$
\begin{aligned}
& \mathrm{E}\left[\pi^{\mathrm{cc}}(\mathrm{c})\right]>\mathrm{E}\left[\pi^{\mathrm{nc}}(\mathrm{c})\right] \text { and } \mathrm{E}\left[\mathrm{w}^{\mathrm{cc}}(\mathrm{c})\right]>\mathrm{E}\left[\mathrm{w}^{\mathrm{nc}}(\mathrm{c})\right] \\
& \mathrm{E}\left[\pi^{\mathrm{cc}}(\mathrm{c})\right]>\mathrm{E}\left[\pi^{\mathrm{cn}}(\mathrm{c})\right] \text { and } \mathrm{E}\left[\mathrm{w}^{\mathrm{cc}}(\mathrm{c})\right]>\mathrm{E}\left[\mathrm{w}^{\mathrm{cn}}(\mathrm{A})\right]
\end{aligned}
$$

Lemma 5 and Proposition 5 and 6 follow from B2 - B5.

\section{Appendix C: Derivations for price competition and unknown costs (section 4.B)}

In the third stage, if neither government is informed, we have

$$
\begin{aligned}
& \mathrm{E}\left[\pi_{\mathrm{i}}^{\mathrm{nn}}(\mathrm{c})\right]=\pi_{\mathrm{i}}^{\mathrm{eg}}(\mathrm{c})+\left(2-\delta^{2}\right)^{2} \sigma^{2} / \Delta^{2}+\delta^{2} \sigma^{2} / \Delta^{2} \\
& \mathrm{E}\left[\mathrm{w}_{\mathrm{i}}^{\mathrm{nn}}(\mathrm{c})\right]=\mathrm{w}_{\mathrm{i}}^{\mathrm{eg}}(\mathrm{c})+\left(2-\delta^{2}\right)^{2} \sigma^{2} / \Delta^{2}+\delta^{2} \sigma^{2} / \Delta^{2} .
\end{aligned}
$$

If both governments are informed, we have

$$
\begin{aligned}
& \mathrm{E}\left[\pi_{\mathrm{i}}^{\mathrm{cc}}(\mathrm{c})\right]=\pi_{\mathrm{i}}^{\mathrm{eg}}(\mathrm{c})+\left(2-\delta^{2}\right)^{2} \sigma^{2} / 16+\delta^{2} \sigma^{2} / 16 \\
& \mathrm{E}\left[\mathrm{w}_{\mathrm{i}}^{\mathrm{cc}}(\mathrm{c})\right]=\mathrm{w}_{\mathrm{i}}^{\mathrm{eg}}(\mathrm{c})+2\left(2-\delta^{2}\right) \sigma^{2} / 16+\delta^{2} \sigma^{2} / 16 .
\end{aligned}
$$

For the asymmetric case, with only firm 1 disclosing information to its government, we have the following equilibrium profits

$$
\mathrm{E}\left[\pi_{1}{ }^{\mathrm{cn}}(\mathrm{c})\right]=\pi_{1}{ }^{\mathrm{eg}}(\mathrm{c})+\left(2-\delta^{2}\right)^{2} \sigma^{2} / 16+\delta^{2} \sigma^{2} / \Delta^{2}
$$




$$
\mathrm{E}\left[\pi_{2}^{\mathrm{nc}}(\mathrm{c})\right]=\pi_{2}{ }^{\mathrm{eg}}(\mathrm{c})+\left(2-\delta^{2}\right)^{2} \sigma^{2} / \Delta^{2}+\delta^{2} \sigma^{2} / 16
$$

and the equilibrium welfare

$$
\begin{aligned}
& \mathrm{E}\left[\mathrm{w}_{1}{ }^{\mathrm{cn}}(\mathrm{c})\right]=\mathrm{w}_{1}{ }^{\mathrm{eg}}(\mathrm{c})+\left(2-\delta^{2}\right) \sigma^{2} / 8+\delta^{2} \sigma^{2} / \Delta^{2} \\
& \mathrm{E}\left[\mathrm{w}_{2}{ }^{\mathrm{nc}}(\mathrm{c})\right]=\mathrm{w}_{2}{ }^{\mathrm{eg}}(\mathrm{c})+\left(2-\delta^{2}\right)^{2} \sigma^{2} / \Delta^{2}+\delta^{2} \sigma^{2} / 16 .
\end{aligned}
$$

Comparing these equilibrium profits and welfare levels yields lemma 6 and proposition 7. Proposition 8 follows from comparing (C1) and (C2) and noting that $\Delta^{2}<16$. 


\section{References}

Brainard, S. L., Martimort, D., 1996. Strategic trade policy design with asymmetric information and public contract. Review of Economic Studies 63, 81-105.

Brander, J.A., 1995. Strategic trade policy, in: Grossman, G, M., Rogoff, K. (eds.), Handbook of International Economics, Vol. 3. North-Holland, Amsterdam, pp. 1395-1455.

Brander, J.A., Spencer, B. S., 1985. Export subsidies and export share rivalry. Journal of International Economics 18, 83-100.

Eaton, J., Grossman, G., 1986, Optimal trade and industrial policy under oligopoly. Quarterly Journal of Economics 101, 383-406.

Edmonson, R.G., 2004. Be careful; trade interests warn government on sharing of export data. Journal of Commerce, April 5, Monday, Export p. 39.

Export-Import Bank, 2005. Report to the U.S. Congress on export credit competition and the ExportImport Bank of the United States, June.

Fershtman, C., Judd, K. L., 1987. Equilibrium incentives in oligopoly. American Economic Review 77, 927-940.

Lahiri, S., Ono, Y., 1997. Asymmetric oligopoly, international trade, and welfare: a synthesis. Journal of Economics 65, 291-310.

Maggi, G., 1998. A note on strategic trade policy design with asymmetric information and public contracts. Review of Economic Studies 65, 623-625.

Maggi, G., 1999. Strategic trade policy under incomplete information. International Economic Review 40, 571-594.

Okajima, Y., 2003. A note on optimal strategic trade policy under asymmetric information. Journal of International Economics 61, 243-246. 
Qiu, L. D., 1994. Optimal strategic trade policy under asymmetric information. Journal of International Economics 36, 333-354.

Qiu, L. D., 2003. Reply. Journal of International Economics 61, 247-248.

Vives, X., 1990. Trade association disclosure rules, incentives to disclose information and welfare. RAND Journal of Economics 21, 409-30. 


\begin{tabular}{|l|l|l|}
\hline $\begin{array}{l}\text { Type of information } \rightarrow \\
\text { Type of competition } \downarrow\end{array}$ & Demand & Cost \\
\hline Quantity competition & $\begin{array}{l}\text { Profits increase } \\
\text { Welfare increases } \\
\text { Prisoner's dilemma }\end{array}$ & $\begin{array}{l}\text { Profits increase } \\
\text { Welfare increases } \\
\text { No prisoner's dilemma }\end{array}$ \\
\hline Price competition & Profits decrease & Profits decrease \\
& Welfare increases & Welfare increases \\
& No prisoner's dilemma & Prisoner's dilemma \\
\hline
\end{tabular}

Table 1: Effects of information disclosure to the government 